\title{
Development and Validation Design of Differentiated Instruction Based Learning Style of Fifth Grade Science Learning
}

\author{
Azizah Nurul Hayati ${ }^{1}$, Subuh Anggoro ${ }^{2}$, Firdaus Ulfah Nur Azizah ${ }^{3}$ \\ \{ $\underline{\text { azizah.nurulhayati.anh@gmail.com }}$, $\underline{\text { subuhanggoro@ump.ac.id }}$, f.ulfahna@gmail.com ${ }^{3}$ \} \\ ${ }^{1}$ SD Negeri Danaraja \\ ${ }^{2}$ Universitas Muhammadiyah Purwokerto \\ ${ }^{3}$ SD Negeri 2 Sampang
}

\begin{abstract}
Differentiated Instruction was first developed by Carol Ann Tomlinson. Differentiated Instruction (DI) is a way of thinking. The purpose of this study was to determine the development of scientific-based designs for students' learning styles and to know the application of scientific-based methods to students' learning styles in science learning in class $\mathrm{V}$ of Elementary Schools, Banyumas District.Differentiated Instruction learning in its application, all students can still learn in one class even though the level of ability of each student is different but still have the same final goal or learning outcomes. This research methodology used was R\&D with the ADDIE method. The hypothesis of this research is that the scientific-based differentiated instruction development design affects learning styles. The result is a lesson implementatation plan based on student learning style. Then, this approach has improved.
\end{abstract}

Keywords: differentiated instruction, learning style, scientific

\section{Introduction}

Elementary school as part of primary education is a critical formal education, because primary education is the foundation for children's education to continue to a higher level of education. The learning process in elementary schools on all the material taught in class is expected to contribute to develop the abilities of students, so that students can to create the potential that exists in themselves and can improve the quality of their lives [1]. However, to achieve optimal learning outcomes requires a learning process. Teachers and schools are a place for students to develop their potential, this is a challenge for both teachers and schools to meet all the needs of students regardless of the academic, social, development and progress of students [2]. Each class in the school is a mixture of different abilities of students. This means that the teacher must be able to manage instructions in the classroom while learning is taking place.

Science subjects are sciences that relate to how to find out about nature systematically, so that science is not only the mastery of a collection of knowledge in the form of facts, concepts, or principles but also a process of discovery. Science/Science is knowledge that provides a huge opportunity for students to instill character values in students [3]. This can be seen based on the 
science curriculum that is structured systematically so that science learning takes place interactively, inspiring, fun, challenging and motivating students to achieve learning goals.

\section{Literature Review}

Differentiated Instruction or Differentiated Learning or Differentiated Teaching was first developed by Carol Ann Tomlinson. Differentiated Instruction (DI) is a way of thinking. It can be interpreted as a philosophy of how to respond to student differences by adapting various teaching techniques to meet the needs of students [4]. In addition, Tomlinson also stated that DI is learning that has been adapted to the needs of students to produce maximum student potential during the learning process. DI learning in its application is that all students can still learn in one class even though the level of ability of each student is different but still has the same ultimate goal or learning achievement for each student. Differentiated Instruction is a learning which in its application refers to different instructions by considering the characteristics of students [5]. Learners have different language and literacy needs so they may not be able to accept what is taught by the teacher with the same teaching technique [6].

\section{Implementation Differentiated Instruction (DI)}

Differentiated Instruction (DI) is a way of thinking, a philosophy of responding to student differences in teacher teaching that is useful for meeting the needs of students in implementing DI learning.

\subsection{Collecting Information about students}

Information collected about students sees three points, namely: readiness (readiness to learn students), interest (interest) and learning profile (learning profile).

\subsubsection{Readiness}

Learning readiness of students according to this means that the initial ability or initial knowledge of students on the material to be studied [7]. The readiness to learn of these students has nothing to do with the IQ of students. The purpose of seeing students' learning readiness is to see the various difficulties experienced by students in learning materials so that they can provide a challenge to students in their learning experience.

\subsubsection{Interest}

Finding out initial information about the interests of students is very important, initial information about the interests of students is beneficial for teachers to attract attention, curiosity and activeness of students in learning activities.[4] Students will appear motivated in themselves when the teacher distinguishes students based on interests to adjust what will be learned with something they already know at the beginning of learning. The teacher distinguishes the interests of students by grouping students who have the same interests, for example sports, music, pets, hobbies. The grouping of students on their interests refers to topics that will later motivate students. 


\subsubsection{Learning profile}

Students will be able to learn more naturally and efficiently if the teacher distinguishes students based on their learning profile [7]. The learning profile in this DI focuses on students' learning styles (audio, visual and kinesthetic), learning preferences which include being alone, in pairs or in groups, and learning atmosphere which provides for calm or accompanied by music. This learning profile can be known by the teacher by distributing a simple questionnaire to students, from this questionnaire the teacher gets information and can distinguish students based on the student's learning profile.

\section{Steps in implementing Differentiated Instruction Learning Pembelajaran}

The steps to apply differentiation learning are to find out each student's maximum ability. Where the teacher's role in the application of differentiated learning is to help students in the learning process. DI learning steps as shown below:

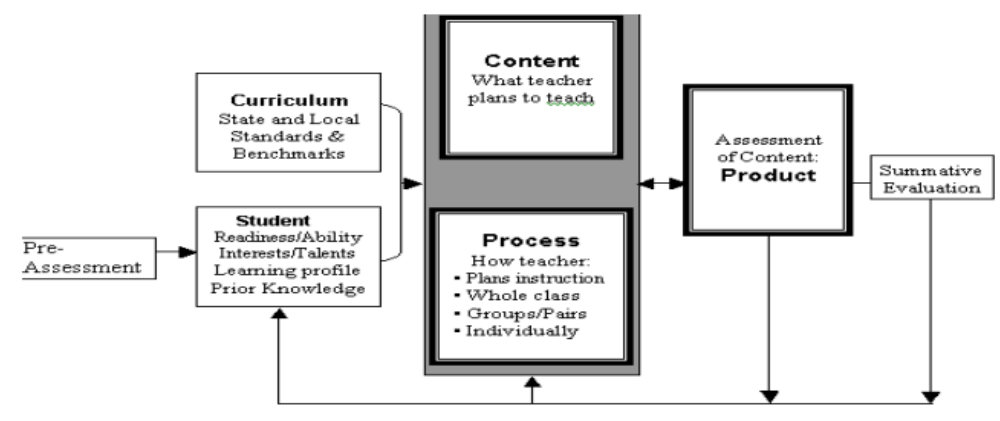

Planning and Implementation Drawings

In the picture, it is explained that the process of implementing DI learning is with the teacher at the beginning of learning doing a pre-test to know the initial abilities of students before implementing learning using DI. From the pre-test, different student achievement results will be obtained. This is very important for teachers to know the ability of students. The level of learning ability of each student is divided into three, namely:

\subsubsection{Independent Level}

Students at the independent level can do assignments independently without the help of their friends. The role of the teacher is only to direct, besides that students can walk alone according to the direction and orders of the teacher.

\subsubsection{Command Rate}

Unlike at the previous level, at this level students need guidance in understanding a concept of learning material. In carrying out assignments, students also need guidance assistance. 


\subsubsection{Frustration Level}

This level is very different from other levels, at this level students are challenging to follow the learning. Students still do not understand the basic concepts of knowledge taught by the teacher so that children will quickly give up and stress on the tasks given by the teacher during learning.

At the three levels above, it can be concluded that in fact all children learn, it's just that the level of children's ability to understand a learning process is different even though they are in the same class. The teacher's very important role must be to research and realize where the level of ability of the students that the teacher teaches before carrying out instructions on the learning process.

\subsection{Planning}

DI learning is designed by distinguishing content, processes, and products based on differences in student readiness, interests, and learning profiles [4].

\subsubsection{Contents}

The content is seen from the learning process and the teacher is responsible for ensuring that all students master and learn the subject matter in the curriculum.

\subsubsection{Process}

Process activities are activities that teachers can do in innovating in the learning process, including:

2.2.2.1 Developing thinking skills, teachers as teachers can teach these skills directly because students who have potential talents need to develop analytical, organizational and critical thinking skills to optimize the talents possessed by students

2.2.2.2 Independent study, in this independent study, students can freely decide on the topic that focuses on learning and determine their own method and time for completion. The teacher's role is to group students based on the same interests so that independent study can run optimally because students have been grouped with the same interests. In addition, the teacher's role is to facilitate students. If students want to explore the focus of a material, the teacher can bridge these students to meet all the needs of students.

\subsubsection{Product}

Products are student learning outcomes that are the result of training, application, and development of what students have learned [4]. In this product, students are free to choose assignments that reflect the abilities, creativity and talents of students. Students do the sequence with the same content and process but in the end it will produce a different ending for each student.

Only a few students have one type of learning style that stands out. In general, students have more than one type of learning style, for example having a combination of kinesthetic and visual learning styles or auditory and visual learning styles, and so on. Identifying of visual, auditory and kinesthetic learning styles distinguishes how we absorb information to determine brain dominance and how learners process information [11]. Learning style can be interpreted as a stable attitude, choice or strategy that determines how a person remembers, receives and obtains learning information. 
Learning styles have many factors that influence the way students learn such as physical, emotional and environmental factors of students [12-13].

\section{RESEARCH METHODS}

The method used in this research is research and development or commonly called Research and Development (RnD). Research and development methods have several types of models. The development design used by the researcher is using the ADDIE model design. This model is known to be effective and dynamic, and it supports the development of learning device designs, book manuals, and online training programs [8-10].

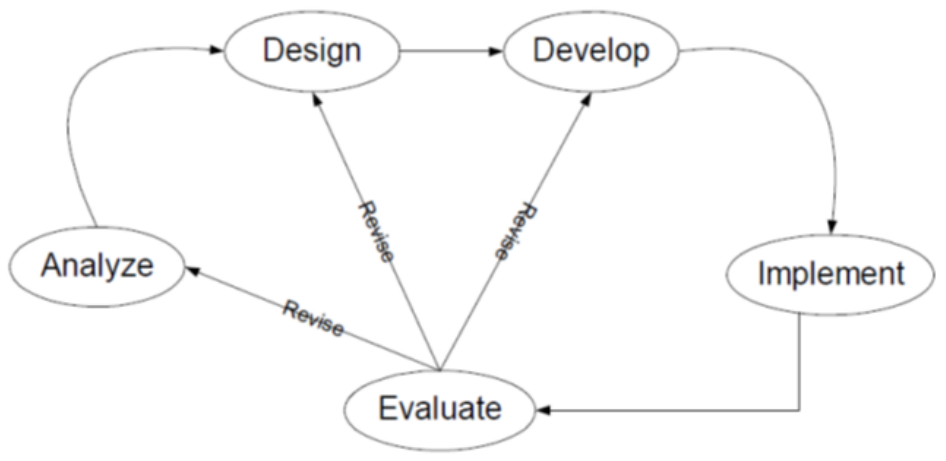

Figure 1. ADDIE Model (Gagne 2005)

\subsection{Analyze}

At this stage, the researchers investigate the need for developing learning models or methods, as well as the feasibility of doing so. The development of new learning methods begins with a review of the weaknesses in previous models or learning methods. Learning is still conventional, so the teacher's material is not optimally absorbed. Differentiated Instruction based on the learning process is used by researchers. The initial readiness or prior knowledge of the material to be studied of the students is analyzed during the analysis stage of DI learning.

\subsection{Design}

This learning model's or method's design is similar to the design of teaching and learning activities. Setting learning objectives, designing scenarios, or teaching and learning activities, designing learning tools, and designing learning tools are indeed part of the planning process for developing DI learning.

a) Determine the learning experience that students must have while participating in learning activities in order to determine the learning tools that will be created.

b) Identifying the appropriate learning strategies in the syllabus and lesson plans, such as DI Learning and learning styles

c) Arrange learning materials/teaching materials in accordance with the Water Cycle research topic.

d) Create a worksheet as a kind of companion for students as they learn.

e) Create evaluation instruments based on the learning objectives that have been developed. 


\subsection{Develop}

At this point, the researcher has realized the previously conceptual framework into a product that is ready for implementation. Learning tools, such as lesson plans and learning media, were created with the new model or method, as planned during the design stage. Following the creation of lesson plans and media, expert assessments are performed, and practitioners receive recommendations for improvements to the learning device plan.

3.4. Implement

At this point, the designs and methods that have been developed are implemented in the classroom learning process. At the time of implementation, the developed designs and methods are applied to the actual conditions that were previously planned, and an initial evaluation is then held to provide feedback on the application of the next model or method. The implementation phase's objectives include: (a) guiding students to achieve the learning objectives set; b) ensuring the occurrence of problem solving or solutions to overcome student gaps; c) Generate competency output in the form of knowledge, skills, and attitudes required to meet learning objectives.

\section{Evaluation}

The evaluation is carried out in two stages, the first with a pretest and the second with a posttest, in order to determine the effectiveness of the development of DI learning. The following is a clearer evaluation to test the effectiveness of the learning design developed with the One Group PretestPosttest Design:

\section{RESULT AND DISCUSSION}

The results of this study use the ADDIE development model which consists of five stages, namely analysis, design, development, implementation and evaluation [8-10]:

\subsection{Analysis}

At this stage, the researcher analyzes the need to develop learning models or methods and analyzes feasibility. The development of new learning methods begins with looking at the problems in the models or learning methods that have previously been applied. Learning is still conventional so that the material provided by the teacher is not optimally absorbed. Researchers use the development of learning process-based Differentiated Instruction. In the analysis stage in DI learning, the students' initial readiness or prior knowledge of the material to be studied is analyzed. The results of discussions and sharing with fifth-grade teachers in Banyumas sub-district found that learning was still very monotonous and did not facilitate the needs of each student. Another problem is that the material presented is not optimally absorbed by students so that the learning process that takes place is still not optimal, therefore Differentiated Instruction is the right alternative in strengthening the concept of learning by adjusting the needs of each student.

Facts in the field regarding the learning process, still do not pay attention to every student's needs. Students have different needs. each student tends to have a different learning style that is useful for learning, processing and communication. Each learner not only tends to one learning style, they also take advantage of specific combinations of learning styles that give them specific natural talents and shortcomings. Basically, students have learning styles (visual, auditory and kinesthetic) but not all of these three components develop in a balanced way, but there is one of the three components that dominate the learning styles of students. One way that schools can do is by using an approach in learning so that students can fulfill their every need and talent. Differentiated 
Instruction is considered to be able to be used to overcome these conditions, because Differentiated Instruction is a way of thinking. It can be interpreted as a philosophy of how to respond to student differences by adapting various teaching techniques to meet the needs of students.

\subsection{Designs}

The plan of this learning model or method has similarities with the design of teaching and learning activities. This planning begins with setting learning objectives, designing scenarios, or teaching and learning activities, designing learning tools, the design will still be conceptual and will make the process of developing DI learning.

4.2.1.1 Determine the learning experience that students need to have while participating in learning activities to determine what learning tools are made. The researcher observed the learning process to the fifth-grade teacher and discussions related to learning using DI

4.2.1.2 Determining the appropriate learning strategy contained in the syllabus and lesson plans, namely DI Learning. Planning learning by compiling lesson plans in accordance with the DI approach and the need of students' learning styles.

4.2.1.3 Arrange learning materials/teaching materials according to the research topic, namely the Water Cycle.

4.2.2 Develop LKPD as a form of companion for students in carrying out learning

4.2.3 Develop evaluation instruments based on the learning objectives that have been formulated.Menyusun instrumen evaluasi yang didasarkan pada tujuan pembelajaran yang telah dirumuskan.

\subsection{Development}

At this stage the researcher, the framework that was previously still conceptual is realized into a product that is ready to be implemented. As at the design stage it was planned, at the development stage, learning tools were made with the new model or method such as lesson plans and learning media. After making lesson plans and media, expert assessments are carried out and practitioners get suggestions for improvements to the learning device plan. After being implemented, there are several revisions and input from the classroom teacher, like the learning media to be more concrete and it looks real, there needs to be improvements

Validator 1 is an expert lecturer who provides comments and suggestions to complete the grid and correct words at several points. Validator 2 provides comments to clarify the differences between each activity between students' learning styles, while validators 3 and 4 are from senior teachers providing comments on the learning process to be clearer and more focused. The detailed validation have shown on Appendix 1-3.

In the validation of the questions there are improvements from validator 1 or from the lecturer, namely the selection of words in sentences to provoke students to be more critical in answering questions and adding pictures so that students can answer based on observations on the picture. Validator 2 adds essay questions so that learning achievement is more accurately measured, not only with multiple choices. After being revised for this pretest question consisting of 20 multiple choice and 5 essays, the purpose of adding essay questions is to get more real data and varied answers based on students' thoughts. Variations of answers obtained by this researcher as data to see the learning achievement of students. 
Validation on the LKPD there are several points that become questions for the first validator, namely about the time allocation which is still unclear and the LKPD grid that does not yet exist. In contrast to the third validator, it provides directions to be reproduced, not only 3 points but can be added up to five questions on the LKPD.

\subsection{Implementation}

At this stage the designs and methods that have been developed are implemented in the learning process in the classroom. At the time of implementation the designs and methods that have been developed are applied to the actual conditions that were previously planned and after implementation, an initial evaluation is then held to provide feedback on the application of the next model or method. The objectives of the implementation phase include:

4.4.1 Guiding students to achieve the learning objectives set.

4.4.2 Guarantee the occurrence of problem solving or solutions to overcome student gaps.

4.4.2 Produce competency output in the form of knowledge, skills, and attitudes needed to achieve learning objectives.
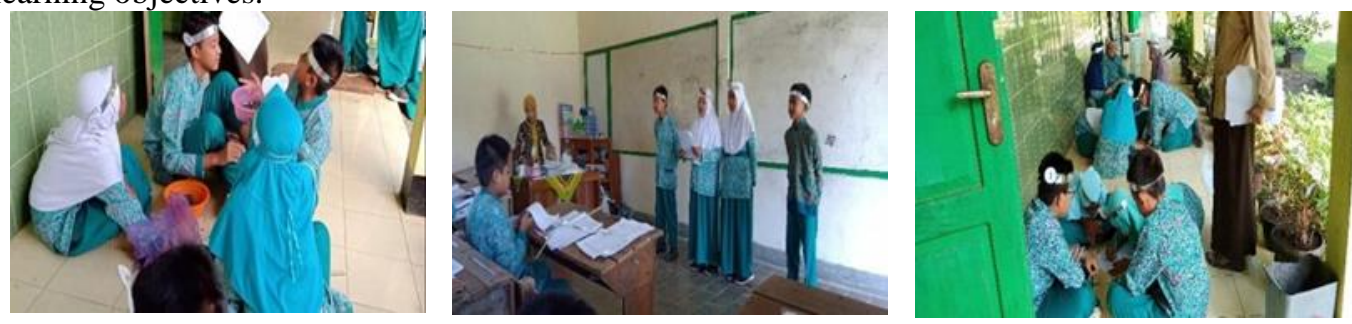

Figure 2. DI Learning Instruction Activities

Tomlinson stated that DI is learning that has been adapted to the needs of students to produce maximum student potential during the learning process. This model in its application is that all students can still learn in one class even though the level of ability of each student is different but still has the same ultimate goal or learning achievement for each student. Differentiated Instruction is a learning which in its application refers to different instructions by considering the characteristics of students [4-6].

\subsection{Evaluation}

Evaluation is carried out in two forms, namely the initial evaluation with a pretest and the final stage with a posttest in order to see the effectiveness of the development of DI learning. A clearer evaluation to test the effectiveness of the learning design developed with the One Group PretestPosttest Design is as follows: 
Table 1. One GroupPretest-Posttest Design

\begin{tabular}{ccc}
\hline Pretest & Treatment & Posttest \\
\hline $\mathrm{O}_{1}$ & $\mathrm{X}$ & $\mathrm{O}_{2}$ \\
\hline
\end{tabular}

Source: Sugiyono (2015)

$\mathrm{X}=$ Treatment with the Scientifically Based Differentiated Instruction learning device and the theme " My Friendly Environment "

$\mathrm{O}_{1} \quad=$ Pretest

$\mathrm{O}_{2} \quad=$ Posttest

Table 1. t-test for Equality of Means

\begin{tabular}{|c|c|c|c|c|c|c|c|c|c|}
\hline & \multicolumn{9}{|c|}{ Levene's Test for Equality of Variances } \\
\hline & \multirow[b]{2}{*}{$\mathrm{F}$} & \multirow[b]{2}{*}{ Sig. } & \multirow[b]{2}{*}{$\mathrm{t}$} & \multirow[b]{2}{*}{$\mathrm{df}$} & \multirow{2}{*}{$\begin{array}{l}\text { Sig. (2- } \\
\text { tailed) }\end{array}$} & \multirow{2}{*}{$\begin{array}{c}\text { Mean } \\
\text { Difference }\end{array}$} & \multirow{2}{*}{$\begin{array}{l}\text { Std. Error } \\
\text { Difference }\end{array}$} & \multicolumn{2}{|c|}{$\begin{array}{l}\text { 95\% Confidence } \\
\text { Interval of the } \\
\text { Difference }\end{array}$} \\
\hline & & & & & & & & Lower & Upper \\
\hline $\begin{array}{l}\text { Equal variances } \\
\text { assumed }\end{array}$ & .398 & .531 & 7.992 & 48 & .000 & 14.20773 & 1.77765 & 10.63353 & 17.78 \\
\hline $\begin{array}{l}\text { Equal variances } \\
\text { not assumed }\end{array}$ & & & 8.025 & 47.382 & .000 & 14.20773 & 1.77046 & 10.64678 & 17.77 \\
\hline
\end{tabular}

Table 1 shown the efectivity of DI learning based learning to student formative scores. The average score of students differ significantly between before and after treatment. As a result, it can be concluded that DI Learning-based learning has an effect on students' formative value on the theme My Friendly Environment.

\section{Conclusion}

Based on the results of the research on the development of the Differentiated Instruction design, it can be concluded that using the ADDIE model have produced a set of Differentiated Instruction development on the learning styles of students. Experts or media validators and language validators contained in the lesson implementation plan developed are in the valid category and deserve to be tested. the average value of the experimental class is higher than the control class. Based on these results, DI Learning-based learning has an effect on students' formative value.

\section{References}

[1] Hidayah N. Pembelajaran tematik integratif di Sekolah Dasar. Terampil: Jurnal Pendidikan dan Pembelajaran Dasar. 2015;2(1):34-49.

[2] Fatimah S, Kartika I. Pembelajaran IPA Sekolah Dasar Berbasis Pendidikan Karakter. AlBidayah: Jurnal Pendidikan Dasar Islam. 2013;5(2).

[3] Tomlinson CA. Differentiation of Instruction in the Elementary Grades. ERIC Digest. 
[4] Coubergs C, Struyven K, Vanthournout G, Engels N. Measuring teachers' perceptions about differentiated instruction: The DI-Quest instrument and model. Studies in Educational Evaluation. 2017 Jun 1;53:41-54.

[5] Watts-Taffe S, Laster BP, Broach L, Marinak B, McDonald Connor C, Walker-Dalhouse D. Differentiated instruction: Making informed teacher decisions. The Reading Teacher. 2012 Dec;66(4):303-14.

[6] Joseph S, Thomas M, Simonette G, Ramsook L. The Impact of Differentiated Instruction in a Teacher Education Setting: Successes and Challenges. International Journal of Higher Education. 2013;2(3):28-40.

[7] Slameto. Belajar dan Faktor-Faktor yang mempengaruhinya. Jakarta: Rineka Cipta. 2003.

[8] Alnajdi SM. The Effectiveness of Designing and Using a Practical Interactive Lesson Based on ADDIE Model to Enhance Students' Learning Performances in University of Tabuk. Journal of Education and Learning. 2018;7(6):212-21.

[9] Astuti I. The Implementation of ADDIE Model in Developing Career Guidance Program in Senior High School. Journal of Education, Teaching and Learning. 2019 Mar 30;4(1):174-9.

[10] Yeh, H.-C., \& Tseng, S.-S. (2019). Using the ADDIE Model to Nurture the Development of Teachers. CALL Professional Knowledge. Educational Technology \& Society, 22(3), 11763647.

[11]Zainun A, Che Endut A, Ainuddin Wahid AA, Rustum Ali Khan AR, Yazid AF. Correlation study between learning style and multiple intelligence among Muslim gifted and talented. ALABQARI: Journal of Islamic Social Sciences and Humanities. 2019.

[12] Elisa TD, Hermita N, Noviana E. Penerapan Model Pembelajaran VAK (Visualization, Auditory, Dan Kinestethic) Terhadap Hasil Belajar IPA Peserta Didik Kelas IV SD Negeri 147 Pekanbaru. Dinamika Jurnal Ilmiah Pendidikan Dasar. 2019 Nov 25;11(1):19-26.

[13]Lutfianis JA, Wijaya AF, Purwanto P. Application Of Problem Based Learning Model Using Education For Sustainable Development Context In Improving Critical Thingking Ability For Junior High School Students At Heat Theory. Dinamika Jurnal Ilmiah Pendidikan Dasar. 2021 Mar 6;12(2):98-103. 